\title{
Comparison of Use of Steroid Alone or in Combination With Cyclophosphamide For the Initial Therapy of Idiopathic Membranous Nephropathy
}

\author{
İdiyopatik Membranöz Nefropatinin Başlangıç Tedavisinde Steroidin Tek \\ Başına veya Siklofosfamid ile Kombine Kullanımının Karşılaştırılması
}

\author{
Sibel Yücel Koçak¹, (1) Özlem Harmankaya², (1) Arzu Özdemir Kayalar¹, (1) Mürvet Yılmaz¹, (D) Süheyla Apaydin¹ \\ ${ }^{1}$ University of Health Sciences Turkey, Bakırköy Dr. Sadi Konuk Education Training and Research Hospital, Clinic of Nephrology, İstanbul, Turkey \\ ${ }^{2}$ Biruni University Medical Faculty, Department of Internal Medicine, Division of Nephrology, İstanbul, Turkey
}

\begin{abstract}
Objective: Idiopathic membranous nephropathy (IMN) is one of the major causes of adult-onset nephrotic syndrome. Despite treatment, approximately $30 \%-40 \%$ of the patients can develop end-stage renal disease (ESRD) within 10-15 years. The objective of this study is to evaluate the efficacy and safety of using oral steroid monotherapy and compare it with steroid and cyclophosphamide (CTX) combination treatment in patients with IMN.

Methods: All native biopsies ( $\mathrm{n}=509)$ performed at our center between 2006 and 2018 were retrospectively examined. In total, 83 (16.3\%) patients were diagnosed with biopsy-proven IMN and 47 patients with IMN presented with nephrotic syndrome. Clinical remission and renal progressions of 20 patients receiving oral steroid monotherapy and 27 patients treated with oral steroid and CTX were evaluated.

Results: All patients in the oral steroid-receiving group achieved remission $[n=12,60 \%$ complete; $n=8,40 \%$ partial remissions (PR)] as compared to the combination therapy-receiving group $(n=9,33.3 \%$, complete; $n=18,66.7 \%$ PR). Steroid monotherapy and steroid + CTX-induced similar complete remission rates (60\% vs $33.3 \% ; \mathrm{p}>0.05)$. Relapse occurred in 6 and 10 patients in the steroid-receiving group (30.0\%) and the steroid + CTX-receiving group (37\%), respectively $(\mathrm{p}>0.05)$. Proteinuria ( $\mathrm{g} /$ day) at baseline, at six months, and at the end of the treatment were not different between the groups [7.58 \pm 4.10 vs $8.74 \pm 4.02, p=0.34$ (baseline); $1,452 \pm 1,579$ vs $2,682 \pm 2,730, p=0.059$ (six months); $362 \pm 416$ vs. $220 \pm 274, p=0.115$ (at the end of treatment)].

Conclusion: This study's results suggest that the application of oral steroid monotherapy can function as an alternative therapeutic regimen for patients with nephrotic IMN. The short-term efficiency and patient tolerability of both regimens were found to be acceptable. Further randomized controlled trials with more subjects are needed to clarify the exact benefits of oral steroid monotherapy in patients with IMN.
\end{abstract}

Keywords: Cyclophosphamide, membranous nephropathy, nephrotic syndrome, steroid monotherapy, immunosuppression

öz

Amaç: İdiyopatik membranöz nefropati (IMN), erişkin nefrotik sendromun başlıca nedenlerinden biridir. Tedaviye rağmen, hastaların yaklaşık \% 30-40'ında 10-15 yıl içinde son dönem böbrek hastalığı gelişebilir. Bu çalışmanın amacı, IMN hastalarında oral steroid monoterapisinin etkinliğini ve güvenliğini değerlendirmek ve steroid/siklofosfamid kombinasyon tedavisi ile karşılaştırmaktır.

Gereç ve Yöntem: Merkezimizde 2006-2018 yılları arasında yapılan tüm biyopsiler ( $n=509)$ geriye dönük olarak incelendi. Seksen üçüne $(\% 16,3)$ biyopsi ile IMN tanısı kondu. Kırk yedisi IMN hastası nefrotik sendrom ile başvurdu. Oral steroid monoterapisi alan 20 hasta ile oral steroid/ siklofosfamid tedavisi alan 27 hastanın klinik remisyon ve renal progresyonları değerlendirildi.

Bulgular: Oral Steroid tedavisi alan grubun 12'sinde (\%60) tam, 8'inde (\%40) kısmi remisyon sağlanırken; kombinasyon tedavisi ile 9 (\%33,3) tam $18(\% 66,7)$ kısmi remisyon sağlandı. Steroid monoterapi ve steroid/siklofosfamid kombinasyon tedavisi ile tam remisyon oranları benzer bulundu (\%60; \%33,3, p>0,05). Steroid alan grupta 6 hastada $(\% 30,0)$, steroid/siklofosfamid alan grupta 10 hastada $(\% 37)$ relaps gelişti $(p>0,05)$. Başlangıçta, altı ayda ve tedavinin sonunda proteinüride (g/gün) gruplar arasında fark yoktu $(7,58 \pm 4,10,8,74 \pm 4,02, p=0,34 ; 1.452 \pm 1.579$, $2.682 \pm 2.730, p=0,059 ; 362 \pm 416,220 \pm 274, p=0,115$, sirasıyla).

Address for Correspondence: Sibel Yücel Koçak, University of Health Sciences Turkey, Bakırköy Dr. Sadi Konuk Training and Research Hospital, Clinic of Nephrology, İstanbul, Turkey

Phone: +90 5055830860 E-mail: fsibelkocak@yahoo.com ORCID ID: orcid.org/0000-0003-3984-4043

Cite as: Yücel Koçak S, Harmankaya Ö, Özdemir Kayalar A, Yılmaz M, Apaydin S. Comparison of Use of Steroid Alone or in Combination With Cyclophosphamide For the Initial Therapy of Idiopathic Membranous Nephropathy. Med J Bakırköy 2021;17:154-160

Received: 15.03 .2021

Accepted: 18.06.2021 
Sonuç: Bu çalışma, oral steroid monoterapisinin nefrotik IMN'li hastalar için alternatif bir terapötik rejim olabileceğini düşündürmektedir. Her iki rejimin kısa vadeli etkinliği ve hasta tolere edilebilirliği kabul edilebilir bulunmuştur. IMN hastalarında oral steroid monoterapisinin kesin faydasını açıklığa kavuşturmak için daha fazla denek ile daha fazla randomize kontrollü çalışmalara ihtiyaç vardır.

Anahtar Kelimeler: Siklofosfamid, membranöz nefropati, nefrotik sendrom, steroid monoterapisi, immünosupresyon

\section{INTRODUCTION}

Globally, membranous glomerulonephritis (GNP) or idiopathic membranous nephropathy (IMN) is one of the most common GNP; however, its treatment is still debatable. In most patients, it initially appears as a primary renal disease but in $20 \%$ of cases, it can be associated with some systemic conditions such as systemic lupus erythematosus, infections, cancer, or drug exposure $(1,2)$. Age (older than 50 years), male gender, renal insufficiency at first diagnosis, and persistent level of proteinuria (above 8-10 g/day) during the first year of the disease are recognized as risk factors for developing end-stage renal disease (ESRD). If patients do not receive any treatment, then about $25 \%-30 \%$ of patients with primary IMN undergo spontaneous remissions and the other 30\%-50\% show progression toward ESRD (3-5). To avoid progression into ESRD, patients can be treated with immunosuppressive drugs. "Who?," "when to treat?," and "whom to treat with potentially toxic therapies?" are the basic questions that need to be answered. The optimal immunosuppressive regimen for patients with IMN remains controversial $(6,7)$. Data relating to the efficacy of different immunosuppressive protocols still need detailed clarification; in particular, there are little data available on the efficacy or benefits of a corticosteroid-based regimen. The objective of the study is to evaluate the efficiency and safety of applying oral steroid monotherapy for treating nephrotic $I M N$, and compare the results with the combination of steroid and cyclophosphamide (CTX) therapy.

\section{METHODS}

\section{Patient Selection}

All native biopsies $(n=509)$ performed at our center between 2006 and 2018 were retrospectively examined. In total, 83 participants were histologically diagnosed with IMN. All patients were screened for the secondary causes of $\mathrm{MN}$ such as hepatitis B and C virus, malignancies, systemic lupus erythematosus, and medication-related consequences. Patients with secondary MN, IMN without nephrotic syndrome, patients who rejected treatment or could not be followed up in our center, and patients who took immunosuppressive therapy before the biopsies were excluded and the remaining 47 patients were included in this study.

\section{Therapeutic Regimen}

Immunosuppressive therapy was started only in patients with nephrotic syndrome and when at least one of the following conditions was observed:

1. The urinary protein excretion persistently exceeds $4 \mathrm{~g} / \mathrm{d}$ and remains at over $50 \%$ of the baseline value;

2. If the patient does not show a progressive decline during antihypertensive and antiproteinuric therapies during an observation period of at least six months; and

3. The presence of severe, disabling, or life-threatening symptoms and serum creatinine ( $\mathrm{SCr}$ ) levels had risen by $30 \%$ or more within 6-12 months from the time of diagnosis and the estimated glomerular filtration (eGFR) is not less than $30 \mathrm{~mL} / \mathrm{min}$ per $1.73 \mathrm{~m}^{2}$ and this change is not explained by superimposed complications.

In total, 47 patients were categorized into 2 groups based on the treatment with immunosuppressors:

1. Oral steroid monotherapy group (Group 1): Patients received oral steroid monotherapy at an initial dose of 1 $\mathrm{mg} / \mathrm{kg} /$ day for 8 weeks, and the dose was reduced by $5 \mathrm{mg}$ every 2 weeks to $30 \mathrm{mg} /$ day. Then, it was reduced by $5 \mathrm{mg}$ every 4 weeks to $5 \mathrm{mg} /$ day for 6 months.

2. Monthly intravenous CTX and oral steroid group (Group 2): Patients received intravenous CTX at a dose of 0.5$0.75 \mathrm{~g} / \mathrm{m}^{2}$ once in every month initially for 6 months, the regimen was combined with a steroid (prednisone: $1 \mathrm{mg} /$ $\mathrm{kg} /$ day), and the prednisone dose was reduced by $5 \mathrm{mg}$ every week. It was withheld temporarily when the patients' leucocyte counts fell below $3,500 / \mathrm{mm}^{3}$ or in case of any infection or other adverse effects. We restarted intravenous CTX administration after the adverse effects had recovered; in these cases, the treatment duration was prolonged. The target blood pressure was less than 130/80 $\mathrm{mmHg}$ during the follow-up. In addition to supportive care, all patients received angiotensin-converting enzyme (ACE) inhibitor/ angiotensin II receptor blocker (ACEI/ARB), diuretics, and lipid-lowering agents. All patients were observed for the treatment effects, recurrence, and side effects.

\section{Clinical Parameters and Definitions}

Nephrotic syndrome was defined with proteinuria $>3.5 \mathrm{~g} /$ day and plasma albumin concentrations $<2.5 \mathrm{~g} / \mathrm{dL}$. We adopted the definition of The Kidney Disease: Improving 
Global Outcomes (KDIGO) practice guidelines on glomerulonephritis, presented in 2012. Complete remission (CR) was defined as urine protein and creatinine ratio (UPCR) $<300 \mathrm{mg} / \mathrm{g}$ or $<0.3 \mathrm{~g} /$ day accompanied by normal serum concentrations of albumin and $\mathrm{SCr}$. Partial remission (PR) was defined as UPCR $\leq 3,500 \mathrm{mg} / \mathrm{g}$ or $<3.5 \mathrm{~g} /$ day or a decrease in proteinuria by at least $50 \%$ from the initial value and $<3.5 \mathrm{~g} /$ day for at least 2 weeks, accompanied by either improvement or the normalization of serum albumin concentration and a stable level of $\mathrm{SCr}$. No remission was defined as no improvement in the urinary protein excretion and serum albumin levels. Patients who did not meet the definitions above were considered to be unresponsive. The remissions were recorded at six months after histological diagnosis. Relapse was defined as nephrotic proteinuria (>3.5 g/day) after a period of remission. The relapse rates from patients with remissions were also recorded. The demographic characteristics and initial laboratory data were recorded. These data included age, sex, blood urea nitrogen, $\mathrm{SCr}$, serum albumin, total cholesterol, and 24-h urinary protein excretion. The date of achieving the first remission for each patient was recorded. The primary outcome was the number of CR or PR in proteinuria. Other outcomes included the time for remission, deterioration of renal function, and adverse effects.

Bakırköy Dr. Sadi Konuk Training and Research Hospital Clinical Research Ethics Committee (2021/61-15.02.2021) approved this study's protocol.

\section{Statistical Analysis}

Categorized variables are represented as numbers; percentages and the mean values were presented with \pm standard deviation or median (minimum-maximum). The differences were compared by independent samples t-test. All statistics were performed using SPSS 23 software. A value of $p<0.05$ was considered significant for this study.

\section{RESULTS}

The data of 83 patients with $\mathrm{MN}$ were retrieved retrospectively, and 47 patients with IMN presented with nephrotic syndrome [20 of them were in the oral steroid monotherapy group (mean age: $49.5 \pm 16.1$ years) and 27 of them were in the steroid + CTX group (mean age: $45.6 \pm 18.0$ years)] were included in the study. There were no significant differences in the means of average age and the distribution of sex between the groups. The follow-up time was $53.00 \pm 39.88$ (6-150) months, but the average length of follow-up in the steroid group was longer than that of the second group $(63.10 \pm 40.99$ months and $45.52 \pm 38.06$ months, respectively) with statistically insignificant difference ( $p>0.05$ ). At the baseline, there was no significant difference in $\mathrm{SCr}$, serum albumin, and daily proteinuria between the groups ( $p>0.05$ ). Proteinuria ( $g /$ day) levels at baseline, at six months, and at the end of the treatment were not different between the groups $[7.58 \pm 4.10$ vs $8.74 \pm 4.02$, $p=0.34$ (baseline); $1.452 \pm 1.579$ vs. $2.682 \pm 2.730, p=0.059$ (six months); $362 \pm 416$ vs. $220 \pm 274, p=0.115$ (at the end of treatment)]. Table 1 shows the demographic features and laboratory parameters of the study population.

Patients were followed until March 2018 or until the occurrence of one of the endpoints of ESRD or death.

The median time to achieve CR was similar [7.78 \pm 5.26 (2-16 months) vs. $8.22 \pm 3.15$ (6-15 months), $p=0.72$, respectively]. The average duration time of remissions in patients with CR was $51.89 \pm 23.57$ (24-144) months in the steroid group, whereas it was $35.78 \pm 33.74(12-108)$ months in the combination group $(p=0.36)$. After the initial treatment, all patients achieved either CR or PR. In the oral steroid monotherapy group, 12 patients (60.0\%) had $C R$, whereas it was only $9(33.3 \%)$ in the other group ( $p=0.069)$. In total, 8 patients in the oral steroid group and 18 patients in steroid + CTX group achieved PR $(p=0.69)$. Table 2 presents a

Table 1. Laboratory parameters and baseline characteristics of patients

\begin{tabular}{|c|c|c|c|}
\hline & Steroid $(n=20)$ & Steroid + CTX $(n=27)$ & $\mathrm{p}$ \\
\hline Gender (female/male) & $10 / 10$ & $16 / 11$ & 0.52 \\
\hline Urea (mg/dL) & $30.15 \pm 11.71$ & $32.74 \pm 10.91$ & 0.83 \\
\hline sCreatinine (mg/dL) & $0.9 \pm 0.44$ & $0.85 \pm 0.36$ & 0.84 \\
\hline Proteinuria (before therapy) (g/day) & $7.58 \pm 4.1$ & $8.74 \pm 4.02$ & 0.96 \\
\hline Proteinuria (6 months) (g/day) & $1.45 \pm 1.57$ & $2.68 \pm 2.73$ & 0.12 \\
\hline Proteinuria (at end follow-up) (g/day) & $0.36 \pm 0.41$ & $0.22 \pm 0.27$ & 0.16 \\
\hline
\end{tabular}

CTX: Cyclophosphamide. Independent sample t-test; Pearson chi-square test; $p<0.05$ 
detailed description of remission times for both groups. The relapse rates were $30 \%$ and $37 \%$ in the steroid group and the steroid + CTX group, respectively (Table 3). The difference was not statistically significant $(p=0.615)$. Proteinuria was significantly decreased and the serum albumin was significantly increased after immunosuppressive treatment in both groups $(p<0.001)$. No patients developed renal failure during the follow-up, whereas two new onset cases of diabetes mellitus in the steroid group and two cases with pulmonary infection in the combined corticosteroid and CTX group were noted.

\section{DISCUSSION}

The natural course of IMN is variable. The conventionally accepted clinical course is the "rule of thirds": in untreated patients, the spontaneous CR of proteinuria occurs in $5 \%$ $30 \%$ of patients at 5 years, spontaneous PR in 25\%-40\% of patients at 5 years, and progression to ESRD in $41 \%$ of patients at 5 years (8). Therefore, predicting the outcome is important for deciding which patient will receive benefits from immunosuppressive therapy. A better risk prediction is based on the clinical parameters of proteinuria and creatinine clearance over a fixed period of time. Male sex, old age ( $>50$ years), hypertension, massive proteinuria (>10 g/24 h), and elevated SCr concentrations at the time of renal biopsies are poor prognostic factors for IMN. The occurrence of relapse or persistence of proteinuria exert a negative impact on renal survival in patients with IMN and nephrotic syndrome. The serum albumin level at diagnosis is the strongest prognostic factor for progression into NS $(9,10)$. The aim in the management of persistent proteinuric disorders is the prevention of renal function deterioration and progression to ESRD $(11,12)$. Declining proteinuria in IMN with the subsequent attainment of a $C R$ or PR correlates with a better renal survival $(13,14)$. Patients can be categorized into three groups according to risk prediction: low-risk, medium-risk, and high-risk groups. The normalization of blood pressure and serum cholesterol levels are important in all the groups.
Patients in the low-risk group (normal $\mathrm{SCr}$ level and proteinuria $<4 \mathrm{~g} /$ day over 6 months of observation) should be treated with diet, ACE inhibitors, and/or angiotensin II type 1 receptor blockers (ARB) instead of aggressive immunosuppressive treatment. In recent years, some studies have shown that ACE inhibitors and ARB combinations are ineffective for treating nephrotic proteinuria, especially $>5$ gr/day (15). Therefore, immunosuppressive treatment should be initiated in patients with proteinuria between 4 and $8 \mathrm{~g} /$ day. If proteinuria persists despite conservative treatment, there is a progression of renal insufficiency accompanied by the development of complications of NS $(16,17)$. In contrast, patients with nephrotic proteinuria and poor prognostic factors should be treated with immunosuppressive drugs. Patients in the high-risk group have persistent proteinuria (>8 g/day) and/or a deteriorating kidney function (16). In patients with IMN and nephrotic proteinuria, the risk of progression to kidney failure should be balanced against the risks and benefits of immunosuppressive therapy (18). The KDIGO guidelines recommend using alternating monthly cycles of oral and intravenous corticosteroids and oral alkylating agents (chlorambucil and CTX) (the Ponticelli regimen) or cyclosporine combination with prednisone. Alkylating agents are the gold standard for the treatment. These all treatments predispose to opportunistic infections and they can even increase the cancer risk threefold. The guideline also suggests the observation without administering immunosuppression for six months because the spontaneous remission rate is already mentioned to be over $30 \%$ (19-21). Alternative regimens for the initial

Table 3. Patients who were followed up until March 2018 or until the occurrence of end-stage renal disease

\begin{tabular}{llll}
\hline & $\begin{array}{l}\text { Steroid } \\
(\mathrm{n}=20)\end{array}$ & $\begin{array}{l}\text { Steroid + CTX } \\
(\mathrm{n}=27)\end{array}$ & $\mathrm{p}$ \\
\hline Complete remission & $60 \%(12)$ & $33.3 \%(9)$ & 0.069 \\
\hline Partial remission & $40 \%(8)$ & $66.7 \%(18)$ & 0.069 \\
\hline No relapse & $70 \%(n=14)$ & $63 \%(n=17)$ & 0.615 \\
\hline
\end{tabular}

CTX: Cyclophosphamide, Pearson chi-square test; $p<0.05$

Table 2. Time to remission according to therapy of patients followed up

\begin{tabular}{|c|c|c|c|}
\hline & Steroid $(n=20)$ & Steroid + CTX $(n=27)$ & $\mathrm{p}$ \\
\hline Mean time to complete remission (mo) & $7.78 \pm 5.26(2-16)$ & $8.22 \pm 3.15(6-15)$ & 0.72 \\
\hline Duration of complete remission (mo) & $51.89 \pm 23.57(24-144)$ & $35.78 \pm 33.74(12-108)$ & 0.36 \\
\hline Mean time to partial remission(mo) & $5.42 \pm 3.52(1-15)$ & $5.71 \pm 2.04(3-8)$ & 0.26 \\
\hline Duration of partial remission (mo) & $38.42 \pm 39.46(5-131)$ & $32.65 \pm 39.04(3-114)$ & 0.88 \\
\hline Follow-up time (mo) & $63.1 \pm 40.99(11-150)$ & $45.52 \pm 38.06(6-134)$ & 0.13 \\
\hline
\end{tabular}

CTX: Cyclophosphamide, Months (mo). Independent samples t-test; $p<0.05$ 
therapy for IMN are calcineurin inhibitors (CNI) such as cyclosporine $\mathrm{A}$ and tacrolimus, anti-proliferative agents such as mycophenolate mofetil, azathioprine, and rituximab (22). Mycophenolate mofetil monotherapy appears to be ineffective, but may be beneficial when administered together with steroids (23). The effects of steroids on IMN are controversial. KDIGO guidelines for glomerulonephritis suggest that corticosteroid monotherapy should not be used for initial therapy. Because the efficacy of corticosteroid monotherapy is still being debated, new studies should be designed to study the efficacy of steroid monotherapy in patients who do not respond to antiproteinuric treatment with RAS blockers over six months. In some of studies, the long-term, alternate-day steroid treatment resulted in a significant reduction in proteinuria and the rate of progression to renal failure (24). An early study reported that a two- to three-month course of high-dose, alternateday prednisone administration resulted in a significant reduction in progression to kidney failure; however, there was no sustained effect on proteinuria (25). Our study demonstrated that steroid monotherapy was as effective as the combined steroid and cytotoxic drug therapy in the reduction of proteinuria and preservation of renal function. These results showed that steroid monotherapy can be used as an alternative treatment for patients with IMN. In a study conducted in Asia, 949 patients with IMN were divided into three groups based on the type of treatment: the steroid group, the combined corticosteroid and CTX group, and the supportive therapy group. Importantly, more than 80 patients in all groups reached CR or PR. This study showed that immunosuppressive drug treatment and the achievement of CR or PR affects renal survival but it must be noted that the proportion of RAS blocker use was only $10 \%$ among the patients. The authors believe that the clinical outcome varies among different races and geography. Steroid therapy, which has not been recommended for IMN in most review articles, appears to be useful at least for Japanese patients (26). Recently, a retrospective study was performed and enrolled patients were divided into two groups based on the interval from biopsy to the initiation of immunosuppression. The patients who received immunosuppressive agents within six months of diagnosis and those who did not receive treatment were compared. In contrast to Western countries, patients with IMN who were treated with any steroid monotherapy may have a better renal preserve and high remission rate in the first year (27).

Recently, a network meta-analysis of RCTs (36 trials, 2018 patients) had been performed and 11 kinds of immunosuppressives were included in the therapies. A meta-analysis showed that a combination of alkylating agents and corticosteroids reduced the risk of ESRD. The total remission rate was $59.2 \%$ in the patients treated with immunosuppressive therapy and $32.4 \%$ in patients treated with non-immunosuppressive agents. Patients with IMN in whom immunosuppressive therapy is warranted, treatment with either an alkylating agent combined with prednisone or cyclosporine is recommended by the KDIGO GN guidelines (28). Patients with IMN diagnosed since 2006 were enrolled in our study. KDIGO GN guideline was presented in 2012, and it was decided to compare oral steroid monotherapy for patients with nephrotic IMN with the protocol of CTX combined with oral steroids. Although Ponticelli et al. (29) showed that the remission rate was $48.1 \%$ in patients treated with steroids and alkylating agents at the ten-year follow-up, our study demonstrated a higher rate of CR in the steroid monotherapy group (60\%). Despite similar baseline characteristics of our study population, the combined therapy group had a higher PR rate $(66.7 \%)$ and a lower $\mathrm{CR}$ rate (33.3\%). Clinical trials using the cyclical treatment of alternating steroids and alkylating agents or $\mathrm{CNI}$ in IMN have shown an excellent kidney survival in those subjects with $\mathrm{CR}$ or PR, even in the long-term. However, the relapses of nephrotic syndrome occur in $25 \%-30 \%$ of patients within 5 years of discontinuation of the therapy with alkylating agents and $40 \%-50 \%$ of patients within 1 year of discontinuation of CNI (30). One study reported that $76 \%$ of 39 patients who received immunosuppressive achieved at least one PR in 5 years after diagnosis, whereas $32.8 \%$ experienced a relapse. The relapse rate was similar to that in our study $30 \%$ in monotherapy group vs $37 \%$ in combined therapy group) (31). Older patients tend to develop a complication of NS and infection because of immunosuppressive treatment. In a study conducted in Japan, older patients were divided into three groups: the prednisolone monotherapy group $(n=35)$, the combined cyclosporine group $(n=66)$, and the supportive therapy group $(n=70)$. Moreover, the frequency of nephrotic syndrome and infection were compared among the groups. The proportion of patients achieving a $30 \%$ decrease in eGFR was not significantly different among the three groups, whereas the proportion of patients achieving $\mathrm{CR}$ and the rate of hospitalization due to infection were significantly higher in the immunosuppressive therapy groups than the supportive group (32). Remission may be delayed for as long as 18-24 months. In a recent study, the meantime to remission was $14.7 \pm 11.4$ months following the third presentation, whereas the meantime to CR was $8.26 \pm 4.04(2-16)$ months in our study. It is better to wait to see the long-term response unless there is a deterioration of renal function or decrease in serum albumin level. In this study, there was no difference in $\mathrm{SCr}$ levels between the 
groups. None of the patients developed renal insufficiency during/in the follow-up period. Significantly decreased proteinuria and elevated serum albumin levels at 6 months of the treatment were observed in both the groups. Two patients exhibited steroid-induced diabetes in the steroid group and two developed infectious diseases in the combination group. All these results showed that the steroid monotherapy induced similar clinical outcomes and side effect profiles compared to the combined therapy group.

\section{CONCLUSION}

It was found that the steroid monotherapy had a beneficial effect on patients with IMN who presented with nephrotic proteinuria. It induced a higher $\mathrm{CR}$ rate and had a favorable effect on the survival rate. It showed an acceptable shortterm efficiency and patient tolerability. Oral steroid monotherapy may be an alternative therapeutic regimen for patients with nephrotic IMN, but further randomized controlled trials are needed to clarify the benefits of early oral steroid monotherapy in patients with IMN.

Footnotes: This study has been presented at the $56^{\text {th }}$ European RenalAssociation - European Dialysis and Transplant Association Congress (ERA/EDTA Congress), 1316 June 2019, Budapest, Hungary.

\section{ETHICS}

Ethics Committee Approval: The study protocol was approved by Bakırköy Dr. Sadi Konuk Training and Research Hospital Clinical Research Ethics Committee (2021/6115.02.2021).

Informed Consent: Informed consent was not obtained since the study is retrospective.

\section{Authorship Contributions}

Concept: S.K.Y., O.H., M.Y., Design: S.K.Y., O.H., A.O., Data Collection or Processing: S.K.Y., A.O., M.Y., Analysis or Interpretation: O.H., S.A., Literature Search: S.K.Y., O.H., A.O., S.A., Writing: O.H., M.Y., S.A.,

Conflict of Interest: No conflict of interest was declared by the authors.

Financial Disclosure: The authors declared that this study received no financial support.

\section{REFERENCES}

1. Makker SP, Tramontano A. Idiopathic membranous nephropathy: an autoimmune disease. Semin Nephrol 2011;31:333-40.

2. Glassock RJ. The pathogenesis of idiopathic membranous nephropathy: a 50-year odyssey. Am J Kidney Dis 2010;56:157-67.

3. Polanco N, Gutiérrez E, Covarsí A, Ariza F, Carreño A, Vigil A et al. Spontaneous remission of nephrotic syndrome in idiopathic membranous nephropathy. Journal of the American Society of Nephrology 2010 Apr 1;21:697-704.

4. van den Brand JA, Hofstra JM, Wetzels JF. Low-molecularweight proteins as prognostic markers in idiopathic membranous nephropathy. Clin J Am Soc Nephrol 2011;6:2846-53.

5. du Buf-Vereijken PW, Branten AJ, Wetzels JF. Idiopathic membranous nephropathy: outline and rationale of a treatment strategy. Am J Kidney Dis 2005;46:1012-29.

6. Ponticelli C, Glassock RJ. Glomerular diseases: membranous nephropathy--a modern view. Clin J Am Soc Nephrol 2014;9:60916.

7. Waldman M, Austin HA 3rd. Treatment of idiopathic membranous nephropathy. J Am Soc Nephrol 2012;23:1617-30.

8. Jha V, Ganguli A, Saha TK, Kohli HS, Sud K, Gupta KL, et al. A randomized, controlled trial of steroids and cyclophosphamide in adults with nephrotic syndrome caused by idiopathic membranous nephropathy. J Am Soc Nephrol 2007;18:1899-904.

9. Sprangers B, Bomback AS, Cohen SD, Radhakrishnan J, Valeri A, Markowitz GS, et al. Idiopathic membranous nephropathy: clinical and histologic prognostic features and treatment patterns over time at a tertiary referral center. Am J Nephrol 2012;36:78-89.

10. Huh H, Lee H, Lee JP, Kim DK, Oh S, Oh YK, et al. Factors affecting the long-term outcomes of idiopathic membranous nephropathy. BMC Nephrol 2017;18:104.

11. Pisoni R, Aros C, Ruggenenti P, Remuzzi G. Mechanisms of progression of chronic renal disease. Saudi J Kidney Dis Transpl 2002;13:250-6.

12. Ruggenenti $P$, Schieppati $A$, Remuzzi G. Progression, remission, regression of chronic renal diseases. Lancet 2001;357:1601-8.

13. Troyanov S, Wall CA, Miller JA, Scholey JW, Cattran DC; Toronto Glomerulonephritis Registry Group. Idiopathic membranous nephropathy: definition and relevance of a partial remission. Kidney Int 2004;66:1199-205.

14. Ponticelli C, Passerini P, Altieri P, Locatelli F, Pappalettera M. Remissions and relapses in idiopathic membranous nephropathy. Nephrol Dial Transplant 1992;7 Suppl 1:85-90.

15. Praga M, Hernández E, Montoyo C, Andrés A, Ruilope LM, Rodicio JL. Long-term beneficial effects of angiotensin-converting enzyme inhibition in patients with nephrotic proteinuria. Am J Kidney Dis 1992;20:240-8.

16. Alfaadhel T, Cattran D. Management of Membranous Nephropathy in Western Countries. Kidney Dis (Basel) 2015 Sep;1:126-37.

17. Radhakrishnan J, Cattran DC. The KDIGO practice guideline on glomerulonephritis: reading between the (guide)lines--application to the individual patient. Kidney Int 2012;82:840-56.

18. Hofstra JM, Fervenza FC, Wetzels JF. Treatment of idiopathic membranous nephropathy. Nat Rev Nephrol 2013;9:443-58.

19. Hofstra JM, Wetzels JF. Management of patients with membranous nephropathy. Nephrol Dial Transplant 2012;27:6-9.

20. Cattran DC. Mycophenolate mofetil and cyclosporine therapy in membranous nephropathy. Semin Nephrol 2003;23:272-7.

21. Ponticelli C, Altieri P, Scolari F, Passerini P, Roccatello D, Cesana $B$, et al. A randomized study comparing methylprednisolone plus chlorambucil versus methylprednisolone plus cyclophosphamide in idiopathic membranous nephropathy. J Am Soc Nephrol 1998;9:444-50.

22. Remuzzi G, Chiurchiu C, Abbate M, Brusegan V, Bontempelli M, Ruggenenti P. Rituximab for idiopathic membranous nephropathy. Lancet 2002;360:923-4.

23. Choi JY, Kim DK, Kim YW, Yoo TH, Lee JP, Chung HC, et al. The Effect of Mycophenolate Mofetil versus Cyclosporine as Combination Therapy with Low Dose Corticosteroids in High-risk 
Patients with Idiopathic Membranous Nephropathy: a Multicenter Randomized Trial. J Korean Med Sci 2018;33:e74.

24. Bolton WK, Atuk NO, Sturgill BC, Westervelt FB Jr. Therapy of the idiopathic nephrotic syndrome with alternate day steroids. Am J Med 1977;62:60-70.

25. Cattran DC, Delmore T, Roscoe J, Cole E, Cardella C, Charron R, et al. A randomized controlled trial of prednisone in patients with idiopathic membranous nephropathy. N Engl J Med 1989;320:2105.

26. Shiiki H, Saito T, Nishitani Y, Mitarai T, Yorioka N, Yoshimura A, et al. Prognosis and risk factors for idiopathic membranous nephropathy with nephrotic syndrome in Japan. Kidney Int 2004;65:1400-7.

27. Chan CK, Lai TS, Chen PM, Chou YH, Wu CF, Chiu YL, et al. Early initiation of immunosuppressive treatment in membranous nephropathy patients. J Formos Med Assoc 2017;116:266-75.

28. Ren S, Wang Y, Xian L, Toyama T, Jardine M, Li G, et al. Comparative effectiveness and tolerance of immunosuppressive treatments for idiopathic membranous nephropathy: A network meta-analysis. PLoS One 2017;12:e0184398.

29. Ponticelli C, Zucchelli P, Passerini P, Cesana B, Locatelli F, Pasquali $S$, et al. A 10-year follow-up of a randomized study with methylprednisolone and chlorambucil in membranous nephropathy. Kidney Int 1995;48:1600-4.

30. Waldman M, Austin HA 3rd. Controversies in the treatment of idiopathic membranous nephropathy. Nat Rev Nephrol 2009;5:46979.

31. McQuarrie EP, Stirling CM, Geddes CC. Idiopathic membranous nephropathy and nephrotic syndrome: outcome in the era of evidence-based therapy. Nephrol Dial Transplant 2012;27:235-42.

32. Yamaguchi M, Ando M, Yamamoto R, Akiyama S, Kato S, Katsuno $\mathrm{T}$, et al. Patient age and the prognosis of idiopathic membranous nephropathy. PLoS One 2014;9:e110376. 